\title{
Stock market manipulation: A comparative analysis of East Asian emerging and developed fi- nancial markets
}

\author{
Syed Qasim Shah ${ }^{\mathrm{a}}$, Izlin Ismail ${ }^{\mathrm{a}}$ and Aidil Rizal bin Shahrin ${ }^{\mathrm{a}}$
}

\begin{abstract}
${ }^{a}$ Faculty of Business and Accountancy, Department of Finance and Banking, University of Malaya, Kuala Lumpur, Malaysia
\section{CHRON I C L E}

Article history:

Received: September 18, 2018

Received in revised format: Sep-

tember 28, 2018

Accepted: October 8, 2018

Available online:

October 8, 2018

Keywords:

Stock Market Manipulation

Firm-specific Characteristics

Emerging Markets

Developed markets A B S T R A C T

The study investigates the firm's specific characteristics of manipulated firms in East Asian emerging and developed markets using hand-collected 244 manipulated cases between 2001 and 2017. The empirical analysis is conducted using panel logistic regression to identify which stocks are more likely to be manipulated. Result shows that large and highly liquid firms were more likely to be manipulated in both emerging and developed markets. Additionally, marginal effect shows that firms with high free float and market capitalization had a higher probability of being manipulated in these markets. On the contrary, profitable firms were less likely to be manipulated in both developed and emerging markets. Limited studies have been conducted to empirically identify the characteristics of the manipulated stocks across the developed and emerging markets. The regulator can use these results to identify possible and expected manipulation and to design enforcement rules, accordingly. Further, investors can take into consideration these characteristics of manipulated stocks while designing their portfolio in order to reduce the portfolio risk.
\end{abstract}

\section{Introduction}

Stock markets have developed and changed dramatically over the period of time where now investors have more trading opportunities, reengineered products, low transaction cost and improved liquidity ${ }^{1}$. These transformations of the stock market are mainly focused on increasing market efficiency. In the finance literature, market efficiency is linked to integrity, in that a market of high integrity will also be efficient (Austin, 2016) ${ }^{2}$. But the important question is whether or not this improved market efficiency has increased market integrity. This is important because one of the main issues in financial markets is the protection of integrity and fairness of the market in order to maintain market efficiency (Aitken et al.,

${ }^{1}$ International Organization of Securities Commissions (IOSCO) presented in their reports that via rapid technological changes and market fragmentation have given rise to market abuse by high frequency traders and direct market access trading (IOSCO reports 2010, 2011).

${ }^{2}$ See for example the statements of objectives on websites of the ASIC (Australia), the SEC (US), the FSA (UK) and the OSC (Canada); fair, efficient and orderly capital markets.

* Corresponding author.

E-mail address: sqshah@siswa.um.edu.my (S. Q. Shah) 
2015, 2018; Aitken \& Harris, 2011). By market integrity, we mean that markets are unimpaired, uncorrupted and sound, whereas fairness means that markets are impartial and equitable (Austin, 2016). The absence of market integrity creates market volatility, which is not always the result of market fundamentals rather most of the time volatility is due to the deterioration of market integrity as a result of poor market design. The primary cause of this deterioration is fraudulent activities in the form of market manipulation. Market manipulation represents major threat to trust and market integrity in capital markets through mispricing and market imperfections (Siering et al., 2017).

This market manipulation harms investors' confidence, resulting in less participation of investors, and adversely affects efficiency, liquidity, integrity and development of the stock market (Guiso et al., 2008; Imisiker \& Tas, 2013; Öğ̈̈t et al., 2009; Punniyamoorthy \& Joy Thoppan, 2012). Despite financial market developments, these negative practices have increased ${ }^{3}$ over the period of time and recently market fraud $^{4}$ is the most serious issue faced by global markets, which constitutes $41 \%$ of overall frauds. (CFA Institute, 2015). Therefore, market manipulation is an important issue to detect and prevent across all of the financial markets including the US and the European and the emerging markets (Aggarwal \& Wu, 2003; Cumming et al., 2015; Gerace et al., 2014; Imisiker \& Tas, 2013; Khwaja \& Mian, 2005; Lee et al., 2013; Mei et al., 2004; Öğüt et al., 2009; Punniyamoorthy \& Joy Thoppan, 2012).

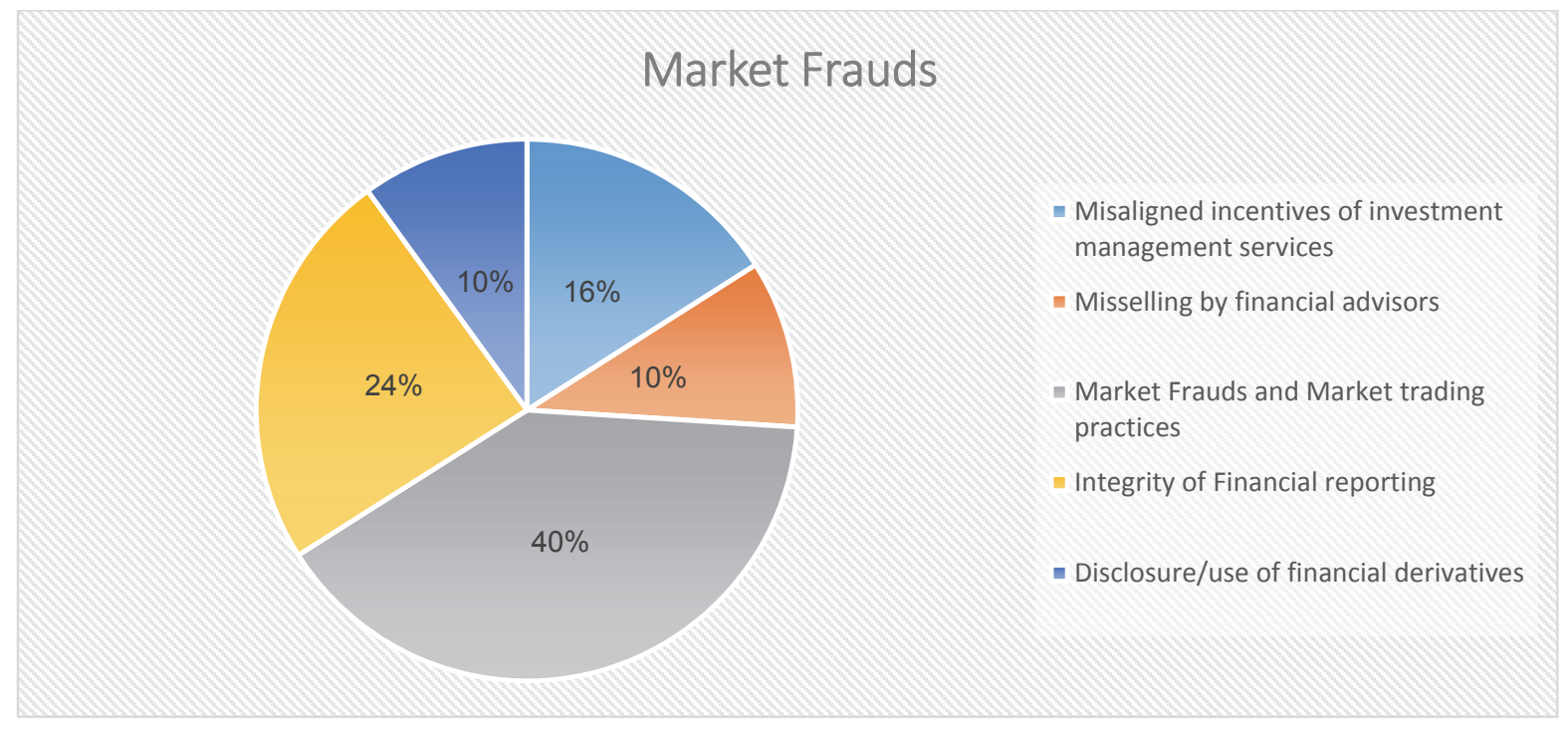

Fig. 1. Market Frauds Distribution

Literature on manipulation mainly focuses on market impact of manipulated activities (Aggarwal \& Wu, 2003; Azad et al., 2014; Gerace et al., 2014; Huang et al., 2012, 2015; Kong \& Wang, 2014; Lee et al., 2013), a few studies, however, have discussed the firm-specific financial characteristics of manipulated firm (Aggarwal \& Wu, 2003; Huang \& Cheng, 2015; Imisiker \& Tas, 2013). Furthermore, the studies on firm's financial characteristics found mixed evidence particularly in terms of liquidity, leverage, and size. On one hand, literature identifies relatively small, illiquid and high leveraged firms as more prone to manipulation (Aggarwal \& Wu, 2006; Chaturvedula et al., 2015; Imisiker \& Tas, 2013; Lee et al., 2013).

\footnotetext{
${ }^{3}$ The NEI Webworld Inc. Went up by $11,400 \%$ in a single trading day in reaction of the false reports spreading on the internet. See Putniņš, T. J. (2012).

Citigroup earned $€ 18.2$ million in profit in 18 seconds because of manipulation of Financial market. See Citygroup: The day Dr Evil wounded a financial giant, Financial Times, 23 August 2006.

Flash Crash 2010: 36-year old individual trader was responsible for the Flash Crash of 6 May, 2010. This individual trader accounted for 20-29 per cent of all sell orders in S\&P 500 futures at a certain point during the Flash Crash. See Tokic, 2015

${ }^{4}$ Illegal market trading practices
} 
On the other hand, studies have identified that relatively large and liquid firms are more prone to manipulation (Comerton-Forde \& Putniņš, 2014; Jiang et al., 2005; Maug, 2002). However, previous literature lacks comparative analyses of developed and emerging markets.

This study empirically examines which firm-specific financial characteristics attract manipulator to target stock in both developed and emerging markets. For this study, we have collected enforced manipulation cases, prosecuted by regulators, from 2001 to 2017 in emerging and developed markets and analyzed their financial characteristics using logistic regression analysis. We believe that this is the first study to comparatively examine the financial characteristics of manipulated firms of developed and emerging markets, particularly in East Asian region, due to the fact that this issue is more prevalent in East Asian markets as these markets are more susceptible to manipulation (Aggarwal \& Wu, 2006; Chan \& Ka Chun Ma, 2013; Huang \& Cheng, 2015; Imisiker \& Tas, 2013; Khwaja \& Mian, 2005; Mei et al., 2004; Sia et al., 2016).

This paper also attempts to equip regulators with empirical facts that can be used to identify and monitor firms that are vulnerable to manipulation. Similarly, regulators can use these firm-specific characteristics to make or update trading rules of stock exchanges. By using findings of this study investors can safeguard themselves against any losses and can design their portfolio by keeping in mind these factors and can diversify accordingly.

\section{Literature Review}

Manipulation in the stock market is carried out by deceiving investors with fictitious trading practices and altering the normal functioning of stock market and price mechanism. Literature categorizes market manipulation into three forms, namely, trade-based manipulation, action-based manipulation and information based manipulation (Allen \& Gale, 1992). In trade-based manipulation the manipulator uses trading activities (buying and selling without using false information or altering firm value), thus creating price momentum. This price momentum is generated by a mass of uninformed traders who exert their market power by trading on one date expecting that their trade will create a moment and prices will go upward resulting in a higher profit (Jarrow, 1992). This profitable manipulation is only possible in markets with information asymmetry (Allen \& Gorton, 1991). The second type of manipulation, informationbased manipulation, is performed by spreading rumors or misleading information (Allen \& Gale, 1992). Here traders form a pool ${ }^{5}$ to purchase shares and subsequently spread rumors about the market value of that stock, and end up selling it at a higher price (Gerace et al., 2014). Usually, rumors are spread by a small group of informed investors for making personal profit at the expense of other investors. These rumors create a market reaction in term of prices; thus leading to overpricing phenomenon in markets (Van Bommel, 2003). In action-based manipulation, the manipulators change the value of the firm by their actions (Allen \& Gale, 1992; Gerace et al., 2014). One form of action-based manipulation, as cited by Bagnoli and Lipman (1996), is using take-over bid. Another instance is informed manipulator's first trade in the wrong direction, to confuse other investors, on the basis of information that he/she possesses. ${ }^{6}$ (Chakraborty \& Y1lmaz, 2004; Huddart et al., 2001; John \& Narayanan, 1997).

Previous literature has found that firm-specific characteristics are significantly contributing towards market manipulation. These financial characteristics may create a trading environment that is more susceptible to manipulation. Studies identified that firms with large market capitalization and higher free float are less likely to be manipulated due to the higher cost of manipulation associated with these firms (Imisiker \& Tas, 2013). The market capitalization of manipulated firms was $\$ 4.83$ billion as compared to $\$ 19.03$ billion for non-manipulated firms (Huang \& Cheng, 2015). Additionally, such firms exert

\footnotetext{
5 The operation of "trading pools" in the United States during the 1920s is the best examples of information-based manipulation

${ }^{6}$ This concept is known as "noise trading". This 'noise' trading is done to confuse investors into believing the informed trader is not trading on his private information.
} 
market power, therefore, manipulator face much more resist against manipulation from the market (Chaturvedula et al., 2015). These studies suggest that mostly manipulation is executed through trading strategies. On the other hand, Jiang et al. (2005) found that manipulated firms are more liquid and have higher market capitalization as compared with other firms in their industry. The authors argued that manipulation is conducted as a result of informed trading (Jiang et al., 2005; Maug, 2002). Comerton-Forde and Putniņš (2014) found mix evidence on size and liquidity and concluded that manipulation is detected in less liquid stock with low market capitalization and lower volatility. They also found that manipulation does not favor the most illiquid stock. By combining the size and liquidity variables in one model they found that manipulators generally prefer stocks that are neither liquid nor illiquid; they, rather, prefer stocks with mid to low level of liquidity.

\section{Data and Methodology}

Our sample is East Asian emerging and developed markets, as this region is more prone to market manipulation as cited in literature review. The classification of market is obtained from MSCI market classification $^{7}, 2015$. East Asia has passed through financial crisis and it faces many new challenges. In general, the region's financial markets are relatively weak, undeveloped and unsophisticated. East Asian financial markets classified as developed markets (Japan, Singapore, Hong Kong and Australia) which perform well on secondary markets on international standards, markets like Korea, Malaysia, Taiwan and Thailand are average, and Indonesia and the Philippines are classified as weak performing markets. Further, studies identified significant bidirectional shock spillovers and integration between Asia-pacific and emerging markets and categorized as weak form efficient and do not follow any pattern (Dewandaru et al., 2016; Li \& Giles, 2015; Malhotra et al., 2015).

The selected cases for this study are limited to only prosecuted manipulation cases by Securities Commission's enforcement actions for our selected sample markets. Following Agrawal and Wu (2006) and unlike Aitken et al. (2015), this study uses those cases against which the regulator has taken some legal action during the sample period. It is quite reasonable to use actual manipulation cases because of their certainty and reliability (Ghafoor et al., 2018). There are total 372 enforced cases for which public information is available. We have excluded those cases where: 1). the date of manipulation is missing; 2). manipulation is done in other than equity markets; 3 ). manipulation is done on derivatives and warrants. Further, those cases are also excluded for which sufficient financial information is not available, these are either delisted or merged. Thus, for the purpose of analysis our sample is restricted to 244 cases.

\section{Table 1}

Distribution of sample

\begin{tabular}{llcc}
\hline Countries & \multicolumn{1}{c}{ Regulator } & Total Cases & $\begin{array}{c}\text { Financial Data Availa- } \\
\text { bilitv }\end{array}$ \\
\hline Panel A & & & 69 \\
Malaysia & Securities Commission Malaysia & 78 & 35 \\
Thailand & Securities and Exchange Commission Thailand & 53 & 30 \\
Taiwan & Securities and Futures Bureau Taiwan & 65 & 59 \\
Panel B & & & 27 \\
Hong Kong & Securities and Futures Commission Hong Kong & 31 & 24 \\
Singapore & Monitory Authority of Singapore & 30 & 244 \\
Japan & Financial Services Agency Japan & 372 & \\
\hline Total & & & \\
\hline
\end{tabular}

Due to these constrains our final sample from emerging markets include Malaysia, Taiwan, and Thailand, and from developed markets including Hong Kong, Singapore, and Japan. These markets have publicly reported all the enforcement actions for this time period. Securities Commission Malaysia, Securities and

\footnotetext{
${ }^{7} \mathrm{MSCI}$ is the renowned information provider for equity markets; covering all market segments from developed, emerging and frontier markets across 75 countries. See https://www.msci.com/market-classification
} 
Exchange Commission Thailand and Securities and Futures Bureau Taiwan deal with manipulation cases in Malaysia, Thailand, and Taiwan, respectively. Whereas in developed markets regulators are Monitory Authority of Singapore, Securities and Futures Commission Hong Kong, and Financial Services Agency Japan. We excluded Indonesia, Philippines as they do not report enforcement actions publicly. For analysis purpose, the sample is divided into three panels. Panel A represents emerging markets, Panel B represents developed markets and Panel C represents an overall sample.

Because the dependent variable for this study is binary/dummy, therefore, the following Stock and Watson (2003) panel logit regression (nonlinear) model is used to estimate the probability of dependent variable. We followed the methodology of Imisiker and Tas (2013) and Shi et al. (2017) and used manipulation as a dummy variable to find its relationship with explanatory variables. Applying bootstrap robustness, both fixed effect and random effect have been used. The data of firm specific financial characteristics is collected from DataStream and annual reports. The econometric model is as follows:

$$
M i t=\alpha+\beta 1 F R i t+\beta 2 M C i t+\beta 3 R O A i t+\beta 4 C R i t+\beta 5 \text { Sit }+\varepsilon i t
$$

Table 2

Definition of variables

\begin{tabular}{ll}
\hline Variable & Description \\
\hline Manipulation (M): & Dummy variable that is one if the stock is manipulated in that year and 0 otherwise \\
Return on Assets (ROA) & Net profit divided by total assets \\
$\begin{array}{l}\text { Free float (FF): } \\
\begin{array}{l}\text { Market capitaliza- } \\
\text { tion(MC): }\end{array}\end{array}$ & The portion of market capitalization available for sale \\
Current Ratio (CR): & Current assets divided by current liabilities \\
SE Index & Yearend index value \\
\hline
\end{tabular}

\section{Result and Discussion}

The model specified above has been applied to find the characteristics of the manipulated firms. Table 3 represents descriptive statistics of the manipulated firms. Descriptive statistics are presented in Table 3 shows that manipulated firms were profitable as return on assets is on average $3.26 \%$ in case of emerging markets and $2.385 \%$ in case of developed markets. Current ratio is also more than 1:1 showing firms' short term liquidity is high in both markets.

Table 3

Summary Statistics of Variables

\begin{tabular}{|c|c|c|c|c|}
\hline Variable & Mean & $S D$ & Min & $\operatorname{Max}$ \\
\hline \multicolumn{5}{|l|}{ Panel A(Emerging Market) } \\
\hline Return on assets & 3.26 & 12.63 & -146.6 & 88.18 \\
\hline Current ratio & 2.16 & 2.30 & 0.01 & 36.22 \\
\hline Market capitalization(Million \$) & 6.04 & 22 & 0.0041 & 35 \\
\hline Free float ratio & 72.6 & 23.5 & 2 & 100 \\
\hline Year-end Index & 4298 & 3356 & 303 & 9307 \\
\hline \multicolumn{5}{|l|}{ Panel B(Developed Market) } \\
\hline Return on assets & 2.385 & 23.139 & -489.3 & 165.8 \\
\hline Current ratio & 2.274 & 4.331 & 0 & 147.01 \\
\hline Market capitalization(Million \$) & 16 & 5.66 & 0.001 & 54 \\
\hline Free float ratio & 51.81 & 24.3 & 4 & 100 \\
\hline Year-end Index & 11131 & 9854 & 146 & 27812 \\
\hline
\end{tabular}

Market capitalization is $\$ 16$ million on average in developed market as compared with $\$ 6.04$ million of emerging markets. While free float ratio shows that manipulated firms have high trading volume in case of emerging markets with an average of $72.6 \%$ as compared with $51.81 \%$ in case of developed markets. 
These financial characteristics determine trading environment investors' preferences to become a shareholder of the relevant firm. As a result, these variables set a trading environment which might be suitable for manipulation (İmişiker et al., 2015).

Table 4 shows the result of panel logit regression using random or fixed effect. As shown in Panel A of Table 4, in case of emerging markets profitable and firms with high current ratio are less prone to manipulation. The result is consistent with the findings of Imisiker and Tas (2013) and Huang and Cheng (2015) in case of emerging markets. A similar trend is found in case of Panel B consistent with the finding of Aggarwal and $\mathrm{Wu}$ (2006) for the case of developed markets, but the current ratio is insignificant. The effect of market capitalization and free float are positive in panel A, thus leading to the conclusion that firms with larger market capitalization and high free float are more likely to be manipulated in emerging markets. Unlike previous studies, this study found that manipulated stocks are more liquid and have higher market capitalization, where manipulation is a result of informed trading rather than successful trade based manipulation (Jiang et al., 2005; Maug, 2002).

In case of manipulation as a result of informed trading manipulator releases false information or rumors about a company in order to inflate or depress its price. Traders, such as company insiders, journalists or stock analysts, can manipulate stock by mixing truth and lies in the information they release. These rumors are informative and, therefore, rational profit-maximizing agents trade on them. Because the rumors are imprecise, prices occasionally overshoot and market manipulation occurs. It is, therefore, found that the type of manipulation associated with highly liquid firms is information-based, not trade-based. This manipulation is usually possible in inefficient markets, where market integrity is always impaired (Bagnoli \& Lipman, 1996; Van Bommel, 2003).

\section{Table 4}

Panel Logit Regression Results

\begin{tabular}{llll}
\hline Variable & Panel A & Panel B & Panel C \\
\hline Return on assets & $-.0207^{*}$ & $-.0054^{*}$ & $-.0110^{* *}$ \\
Current ratio & $(.0070)$ & $(.0031)$ & $(.0033)$ \\
& $-.4951^{* *}$ & -.0453 & $-.0861^{* *}$ \\
Market capitalization & $(.2155)$ & $(.05125)$ & $.05138)$ \\
& $.5362^{*}$ & -.0897 & $(.0901)$ \\
Free float ratio & $(.1398)$ & $(.07657)$ & $1.391 * *$ \\
& $1.338^{*}$ & $.6762 *$ & $(.3915)$ \\
Year-end Index & $(.5030)$ & $(.4065)$ & $-.0865^{* *}$ \\
Constant & -.0979 & $-.0297 * *$ & $(.0257)$ \\
\cline { 2 - 4 } & $(.0734)$ & $(.0110)$ & - \\
\hline Likelihood & & $-2.2344 * *$ & -649.60381
\end{tabular}

Table 5

Hausman test

\begin{tabular}{l|lll}
\hline Measures & Panel $\boldsymbol{A}$ & Panel $\boldsymbol{B}$ & Panel $\boldsymbol{C}$ \\
\hline chi2 & 18.20 & 8.86 & 16.68 \\
Prob $>$ chi 2 & 0.0027 & 0.1149 & 0.0051 \\
Decision & Fixed Effect is appropriate* & Random effect is appropriate** & Fixed Effect is appropriate $* * *$ \\
\hline
\end{tabular}

Note: * Housman test shows the high and significant value of chi-square, thus accepting H1 that fixed effect is appropriate.

** Housman test shows the low and insignificant value of chi-square, thus accepting H0 that random effect is appropriate

*** Housman test shows the high and significant value of chi-square, thus accepting $\mathrm{H} 1$ that fixed effect is appropriate

On the contrary, market capitalization is negative related to manipulation but insignificant in case of developed markets, showing that large firms are less likely to be manipulated. This result was expected 
due to the increasing transaction costs of manipulators if they manipulate a larger size firm. Additionally, larger stocks on the market do exhibit more executive power over the firm with higher free float so the manipulators may face much more resistance from the current managers of the relevant firm.

Panel C shows that in Asian Market larger firms and firms with high liquidity are more prone to manipulation, while profitable firms and firms with high current ratio are less likely to be manipulated. Maug (2002) shows that an informed trader can most easily profit from trades in highly liquid stocks, which provide more opportunities to camouflage the informed trades. Similarly, Jiang et al. (2005) find that the manipulated stock is of comparable size and is more liquid than other companies in its industry supporting manipulation as a result of informed trading. Information based manipulation is only possible in inefficient markets suggesting that Asian markets are inefficient and manipulators manipulate stock via spreading rumors in the markets therefore deteriorating market integrity.

The marginal effect of financial characteristics of manipulated stocks in Panel A shows that $1 \%$ change in free float rate will bring $0.27 \%$ probability of manipulation in a particular stock, whereas $1 \%$ change in market capitalization creates the probability of manipulation by $0.11 \%$. Similarly, in developed markets result shows that $1 \%$ change in free float will increase $.45 \%$ probability of that stock being manipulated. Panel $\mathrm{C}$ shows that free float rate increases the chance of manipulation by $0.25 \%$. These marginal effects show that free float and market capitalization are the main determinants of market manipulation, and usually, manipulator considers these factors for possible manipulation in both developed and emerging markets.

Table 6

Marginal effects

\begin{tabular}{llll}
\hline Variables & Panel A & Panel B & Panel C \\
\hline Return on assets & $-.0042^{* *}$ & $-.0017^{*}$ & $-.0020^{*}$ \\
Current ratio & $(.001)$ & $(0.0009)$ & $(.000)$ \\
& $-.1024^{*}$ & -.0172 & $(.0156$ \\
Market capitalization & $(.048)$ & $(.019)$ & $.0405)$ \\
& $.1110^{* *}$ & .018 & $(.010)$ \\
Free float ratio & $(.025)$ & $(.069)$ & $.253^{* *}$ \\
& $.2769^{*}$ & $.452^{* *}$ & $(.070)$ \\
Year-end Index & $(.157)$ & $(.147)$ & $-.015^{*}$ \\
& $-.0202^{*}$ & $-.018^{* *}$ & $(.006)$ \\
\hline
\end{tabular}

Note: Values represent dy/dx, Std. Err., and $\mathrm{P}>|\mathrm{z}|$

These results are different from the previous studies conducted for emerging markets and developed markets (Aggarwal \& Wu, 2003; Chaturvedula et al., 2015; Huang \& Cheng, 2015; Imisiker \& Tas, 2013; Lee et al., 2013), where firms with large market capitalization and higher free float were less likely to be manipulated. Unlike previous studies, this study found that manipulated stocks are more liquid and have higher market capitalization, where manipulation is a result of informed trading rather than successful trade based manipulation (Jiang et al., 2005; Maug, 2002). Manipulator releases false information or rumors about a company in order to inflate or depress its price. Traders, such as company insiders, journalists or stock analysts, can manipulate stock by mixing truth and lies in the information they release. These rumors are informative and, therefore, rational profit-maximizing agents trade on them. Because the rumors are imprecise, prices occasionally overshoot and market manipulation occurs. It is, therefore, found that the type of manipulation associated with highly liquid firms is information-based, not tradebased. This manipulation is usually possible in inefficient markets, where market integrity is always impaired. 


\section{Conclusion}

Manipulation affects market integrity which is one of the important requirements of financial markets to maintain market efficiency. Therefore, unusual market activity should be monitored and appropriate enforcement action must be taken. This study has investigated the characteristics of a stock that manipulators pick for successful manipulation. For this purpose, we have analyzed the financial characteristics of those manipulation cases against which enforcement actions were taken by regulators. It has found that firms with higher market capitalization and high free float were more prone to manipulation and involve information- based manipulation. Mainly this is possible in inefficient markets, where prices are not fair and do not reflect their true values. Hence, we have concluded that irrespective of recent developments in financial markets, these markets are still facing the issue of market integrity, where manipulators are manipulating highly liquid firms via rumors.

Our research is limited to prosecuted and publicly available cases, leaving all other cases where limited information is available about manipulation. The results can be more robust if future research targets all manipulation cases of emerging and developed markets of Asia. Further, the additional variables related to corporate governance and accounting methods used by these firms can be explored considering management involvement in manipulation.

\section{References}

Aggarwal, R. K., \& Wu, G. (2003). Stock market manipulation-theory and evidence. Paper presented at the AFA 2004 San Diego Meetings.

Aggarwal, R. K., \& Wu, G. (2006). Stock market manipulations. The Journal of Business, 79(4), 19151953.

Aitken, M., Cumming, D., \& Zhan, F. (2015). Exchange trading rules, surveillance and suspected insider trading. Journal of Corporate Finance, 34, 311-330.

Aitken, M. J., Aspris, A., Foley, S., \& Harris, F. H. d. B. (2018). Market fairness: The poor country cousin of market efficiency. Journal of Business Ethics, 147(1), 5-23.

Aitken, M. J., \& Harris, F. d. B. (2011). Evidence-Based Policy Making for Financial Markets: A* Fairness and Efficiency Framework for Assessing* Market Quality. The Journal of Trading, 6(3), 22-31.

Allen, F., \& Gale, D. (1992). Stock-price manipulation. Review of financial studies, 5(3), 503-529.

Allen, F., \& Gorton, G. (1991). Stock price manipulation, market microstructure and asymmetric information. Retrieved from

Austin, J. (2016). What Exactly Is Market Integrity? An Analysis of One of the Core Objectives of Securities Regulation.

Azad, A. S., Azmat, S., Fang, V., \& Edirisuriya, P. (2014). Unchecked manipulations, price-volume relationship and market efficiency: Evidence from emerging markets. Research in International Business and Finance, 30, 51-71.

Bagnoli, M., \& Lipman, B. L. (1996). Stock price manipulation through takeover bids. The RAND Journal of Economics, 124-147.

Chakraborty, A., \& Y1lmaz, B. (2004). Informed manipulation. Journal of Economic theory, 114(1), 132152.

Chan, C.-H., \& Ka Chun Ma, A. (2013). Order-based manipulation: evidence from Hong Kong stock market. Journal of Financial Crime, 21(1), 111-118.

Chaturvedula, C., Bang, N. P., Rastogi, N., \& Kumar, S. (2015). Price manipulation, front running and bulk trades: Evidence from India. Emerging Markets Review, 23, 26-45.

Comerton-Forde, C., \& Putniņš, T. J. (2014). Stock price manipulation: Prevalence and determinants. Review of Finance, 18(1), 23-66.

Cumming, D., Dannhauser, R., \& Johan, S. (2015). Financial market misconduct and agency conflicts: A synthesis and future directions. Journal of Corporate Finance, 34, 150-168. 
Dewandaru, G., Masih, R., \& Masih, A. M. M. (2016). Contagion and interdependence across AsiaPacific equity markets: An analysis based on multi-horizon discrete and continuous wavelet transformations. International Review of Economics \& Finance, 43, 363-377.

Gerace, D., Chew, C., Whittaker, C., \& Mazzola, P. (2014). Stock Market Manipulation on the Hong Kong Stock Exchange. Australasian Accounting Business \& Finance Journal, 8(4), 105.

Ghafoor, A., Zainudin, R., \& Mahdzan, N. S. (2018). Factors Eliciting Corporate Fraud in Emerging Markets: Case of Firms Subject to Enforcement Actions in Malaysia. Journal of Business Ethics, 122.

Guiso, L., Sapienza, P., \& Zingales, L. (2008). Trusting the stock market. The journal of Finance, 63(6), 2557-2600.

Huang, Y. C., \& Cheng, Y. J. (2015). Stock manipulation and its effects: pump and dump versus stabilization. Review of Quantitative Finance and Accounting, 44(4), 791-815.

Huang, Y. C., Hou, N. W., \& Cheng, Y. J. (2012). Illegal insider trading and corporate governance: evidence from Taiwan. Emerging Markets Finance and Trade, 48(sup3), 6-22.

Huddart, S., Hughes, J. S., \& Levine, C. B. (2001). Public disclosure and dissimulation of insider trades. Econometrica, 69(3), 665-681.

İmişiker, S., Özcan, R., \& Taş, B. K. O. (2015). Price Manipulation by Intermediaries. Emerging Markets Finance and Trade, 51(4), 788-797.

Imisiker, S., \& Tas, B. K. O. (2013). Which firms are more prone to stock market manipulation? Emerging Markets Review, 16, 119-130.

Jarrow, R. A. (1992). Market manipulation, bubbles, corners, and short squeezes. Journal of financial and Quantitative Analysis, 27(03), 311-336.

Jiang, G., Mahoney, P. G., \& Mei, J. (2005). Market manipulation: A comprehensive study of stock pools. Journal of Financial Economics, 77(1), 147-170.

John, K., \& Narayanan, R. (1997). Market Manipulation and the Role of Insider Trading Regulations*. The Journal of Business, 70(2), 217-247.

Khwaja, A. I., \& Mian, A. (2005). Unchecked intermediaries: Price manipulation in an emerging stock market. Journal of Financial Economics, 78(1), 203-241.

Kong, D., \& Wang, M. (2014). The manipulator's poker: order-based manipulation in the Chinese stock market. Emerging Markets Finance and Trade, 50(2), 73-98.

Lee, E. J., Eom, K. S., \& Park, K. S. (2013). Microstructure-based manipulation: Strategic behavior and performance of spoofing traders. Journal of Financial Markets, 16(2), 227-252.

Li, Y., \& Giles, D. E. (2015). Modelling volatility spillover effects between developed stock markets and asian emerging stock markets. International Journal of Finance \& Economics, 20(2), 155-177.

Malhotra, N., Tandon, K., \& Tandon, D. (2015). Testing the Empirics of Weak Form of Efficient Market Hypothesis: Evidence from Asia-Pacific Markets. IUP Journal of Applied Finance, 21(4), 18.

Maug, E. (2002). Insider trading legislation and corporate governance. European Economic Review, 46(9), 1569-1597.

Mei, J., Wu, G., \& Zhou, C. (2004). Behavior based manipulation: theory and prosecution evidence. Available at SSRN 457880.

Öğüt, H., Doğanay, M. M., \& Aktaş, R. (2009). Detecting stock-price manipulation in an emerging market: The case of Turkey. Expert Systems with Applications, 36(9), 11944-11949.

Punniyamoorthy, M., \& Joy Thoppan, J. (2012). ANN-GA based model for stock market surveillance. Journal of Financial Crime, 20(1), 52-66.

Shi, W., Connelly, B. L., \& Hoskisson, R. E. (2017). External corporate governance and financial fraud: cognitive evaluation theory insights on agency theory prescriptions. Strategic Management Journal, 38(6), 1268-1286.

Sia, S. K., Hsu, C., \& Teo, W. J. (2016). Implementing asean stock trading links: Tackling the institutional challenges.

Siering, M., Clapham, B., Engel, O., \& Gomber, P. (2017). A taxonomy of financial market manipulations: establishing trust and market integrity in the financialized economy through automated fraud detection. Journal of Information Technology, 32(3), 251-269. 
Van Bommel, J. (2003). Rumors. The journal of Finance, 58(4), 1499-1520.

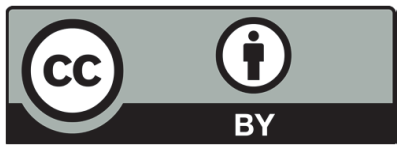

(C) 2019 by the authors; licensee Growing Science, Canada. This is an open access article distributed under the terms and conditions of the Creative Commons Attribution (CCBY) license (http://creativecommons.org/licenses/by/4.0/). 